\title{
Medical staff services quality to patients satisfaction based on SERVQUAL dimensions
}

\author{
Febri Endra Budi Setyawan ${ }^{1}$, Stefanus Supriyanto ${ }^{2}$, Feny Tunjungsari ${ }^{3}$, \\ Wa Ode Nurlaily Hanifaty ${ }^{4}$, Retno Lestari ${ }^{5}$ \\ ${ }^{1,2}$ Doctoral Program of Public Health, Faculty of Public Health, Universitas Airlangga, Indonesia \\ ${ }^{1,3,4}$ Faculty of Medicine, University of Muhammadiyah Malang, Indonesia \\ ${ }^{5}$ Study Program of Nursing Science, Faculty of Medicine, University of Brawijaya, Indonesia
}

\begin{abstract}
Article Info
Article history:

Received Dec 09, 2018

Revised Jan 18, 2019

Accepted Feb 23, 2019

\section{Keywords:}

Patients' satisfaction

Services quality

SERVQUAL

ABSTRACT

Hospital service quality was a degree of discrepancy between patients' perceptions and their expectations about hospitals services. Service quality which was provided by medical staff emphasizes the actual hospital service process. In the hospital, patients' satisfaction could be widely used to determine hospital service quality. The purpose of this study was to analyze the influence of medical staff services quality on patients satisfaction based on SERVQUAL dimensions. This study used an analytic observational design with Cross-sectional approach. There were 314 respondents taken from inpatients hospital admission using simple random sampling. Based on regression analysis results, five dimensions of health services quality affect patients' level of satisfaction and obtained the equation of $\mathrm{Y}=0.026+0.226 \mathrm{X} 1+0.332 \mathrm{X} 2+0.1 \mathrm{X} 3+0.075 \mathrm{X} 4+0.235 \mathrm{X} 5$, this explained that patients' satisfaction was affected by all dimensions of health service quality (RATER) simultaneously. However, different values will be obtained if all dimensions were measured separately, range from $10 \%$ to $33.2 \%$. It could be concluded that patients' satisfaction were influenced by the quality of medical staff services through its five components: reliability, assurance, tangible, empathy and responsiveness.
\end{abstract}

Copyright $@ 2019$ Institute of Advanced Engineering and Science. All rights reserved.

\section{Corresponding Author:}

Febri Endra Budi Setyawan,

Doctoral Program of Public Health,

Universitas Airlangga, Mulyorejo, Surabaya, Indonesia.

Email: febri_dirgantara@yahoo.co.id,febri.en.budi-2017@fkm.unair.ac.id

\section{INTRODUCTION}

Competition in the provision of health services triggers improvements in efficiency, productivity and quality of care. Increased competition among health services influence patients to choose a hospital with a good track record. Hospitals compete for patients by improving its quality of services; it is as a vital element to achieve patients' satisfaction and loyalty towards the hospitals. Hospital service quality was a degree of discrepancy between patients' perceptions and their expectations about hospitals services. Service quality which was provided by medical staff emphasizes the actual hospital service process. In the hospital, patients' satisfaction could be widely used to determine hospital service quality. Previous studies investigated that patient loyalty and service quality were affected by patient satisfaction [1-3].

Healthcare quality can be categorized into three components: quality of structure (infrastructure and material), quality of process (services provided by medical staff) and outcomes (effects of care provision on patients' satisfaction). In addition, creating better access to health care from institutional barriers is also important to achieve the highest standards for quality care. Previous study stated that several dimensions could determine the standards of care: human resources, process, policies and infrastructures. In addition, 
high quality of health services could be obtained by listening to their patients and involving them in the heath services [4-6].

Patients are the determinants of health care system so it is important to provide highest priority for better efficient and effective quality of care. Improving health services into a friendly hospital and understanding both medical staff and patient's satisfaction could strengthen the management of health care institutions. Other factors that need to be improved are communication skill of medical staff, health finance that should be made easily available to the patient and health policy [7-8].

Service quality could be measured by the most widely used instrument of SERVQUAL, which was developed by Parasuraman of the Marketing Science Institute with five dimensions of service quality. SERVQUAL/RATER instrument consists of: Reliability, Assurance, Tangibles, Empathy, Responsiveness, with each statement used twice to measure expectations and perception. Service quality determinants can be divided into two main categories: the tangible and intangible factors. Tangible dimension refers to physical facilities, medical staff, communication and others. Intangible dimension consists of four sub-sectors which then categorized into reliability, responsiveness, assurance and empathy. Previous study demonstrated that all service dimensions had positive relationships with patients' satisfaction. Tangibility, reliability and assurance were the most predictors of patient's satisfaction. SERVQUAL dimensions provide a positive insight to the health institutions where they should focus to provide better services to the patients [9-13]. Therefore, the purpose of this study was to analyze the influence of medical staff services quality on patients satisfaction based on SERVQUAL dimensions.

\section{RESEARCH METHOD}

This study was analytic observational design with Cross-sectional approach. There were 314 respondents taken from inpatients hospital admission using simple random sampling. The population in this study were all patients in a third class ward of a hospital. To minimize the confounding factors, the researchers restricted respondents into several inclusion criteria: [1] have undergone treatment for more than 2 days, [2] mentally healthy, [3] willing to be respondent and [4] age 19-50 years. This study was conducted on July 2018 in one hospital.

Informed consent was signed after each respondent had been explained about the research and the general purpose of this study. Researchers also ensured that the respondents understand the study and that the subject freely to participate. Ethical approval was gained from Ethics Committee of University of Muhammadiyah Malang, June 2018 (Reg.No: E.5.a/219/KEPK-UMM/VI/2018). Written procedure approval from the site was also obtained.

Medical staff services quality was measured using five service dimensions according to Parasuraman, which was based on the RATER (Reliability, Assurance, Tangible, Empathy and Responsivenes), with sub variables:

- Reliability is the ability of medical staff to provide services promptly, accurately, reliably and satisfactorily.

- Assurance is a guarantee of service of knowledge, politeness, the ability of medical staff to build patient's trust in the medical services provided.

- Tangibles are physical evidence, it is the appearance of medical staff and medical devices used when conducting medical services

- Empathy is the ability of being sincere and provides individualized attention to patients by trying to understand the patient's complaints thoroughly.

- Responsiveness is the ability of medical staff to provide prompt and appropriate services to patients by responding to patient complaints and resolving complaints of patients and their families and conveying clear information to patient complaints.

Patient's level of satisfaction was measured based on patient's satisfaction indicators "Decree of the Minister of State for Administrative Reform Number 25/KEP/M.PAN/2/2004" which was modified according to particular medical staff services in the hospital. Questionnaires were given to 314 respondents who were hospitalized patients at the Hospital. Respondents gave their opinions regarding the quality of services performed by medical staff based on five dimensions of service quality. Data was analyzed using Pearson's correlation to see the relationship between variables and linear regression was used to determine which independent variables that had the most important predictor of dependent variable and also confounder variables simultaneously.

Int. J. Public Health Sci. Vol. 8, No. 1, March 2019: 51 - 57 


\section{RESULTS AND ANALYSIS}

\subsection{Correlation of medical staff service quality dimensions with patient's level of satisfaction}

The purpose of this study was to analyze the influence of medical staff services quality on patients satisfaction based on SERVQUAL dimensions. As seen on Table 1, the results showed that patients satisfied with most service quality dimensions of medical staff. However, one indicator on the dimension of reliability was categorized as unsatisfactory (2.76), medical staff visite time (patient's examination) was not carried out exactly according to the time stated \pm 15 minutes from the specified schedule.

Table 1. Overall medical staff service quality dimensions score

\begin{tabular}{lc}
\hline \multicolumn{1}{c}{ Service Dimensions } & Mean \\
\hline Reliability & 3.62 \\
Medical staff is able to make an accurate diagnosis and in a timely manner & 3.85 \\
Patient's condition is improved following treatment & 2.76 \\
Medical staff visite time (patient's examination) is carried out exactly according to the time \\
stated \pm 15 minutes from the specified schedule. & 4.00 \\
Assurance & 3.77 \\
Patient's examination is carried out by a medical staff (according to the schedule on board) & 3.70 \\
Patients' examination was done carefully & 3.86 \\
Medical staff is able to check the patient thorougly & 4.09 \\
Medical staff do not discriminate between patients & 4.07 \\
Tangible & 4.33 \\
The appearance of medical staff seems convincing & 3.81 \\
The tool used to do the inspection looks good & 3.93 \\
Medical staff use specific attributes that are easily known and read by patients & 3.82 \\
Empathy & \\
Medical staff give attention to all patients & 3.55 \\
Medical staff asks for patients' complaint & 3.64 \\
Medical staff are being patient in dealing with both patient's and family's complaints & 3.44 \\
Responsiveness & 3.39 \\
Medical staff responds quickly and effectively to patient's complaints & \\
Medical staff responds to each patient's complaint & \\
Medical staff explains the results of the examination and patient understands the explanation & \\
Medical staff provides effective communication, information and education to patients & \\
\hline
\end{tabular}

Based on the results of the total medical staff service quality dimensions score, it is known that the dimension of tangible had the highest score of 4.16 as shown in Table 2. Dimension of tangible concerns with hospital facilities, equipment, medical staff and all materials that could be perceived by human senses.

Table 2. Total medical staff service quality dimensions score

\begin{tabular}{cc}
\hline Service Dimensions & Mean \\
\hline Reliability & 3.41 \\
Assurance & 3.82 \\
Tangible & 4.16 \\
Empathy & 3.85 \\
Responsiveness & 3.54 \\
\hline
\end{tabular}

Table 3 reveals the level of patient's satisfaction in the hospital, it was found that most $(59.55 \%)$ respondents felt quite satisfied with the services of medical staff. The relationship of medical staff service quality dimensions with patient's level of satisfaction was analyzed by a linear regression test. Linear test results are presented in Table 4. Based on Table 4, the correlation value of the quality of medical staff services with a level of satisfaction is 0.969 and the determinant coefficient or regression model is $93.9 \%$.

Table 3. Level of patients' satisfaction in hospital

\begin{tabular}{ccc}
\hline Level of Patients' Satisfaction & Frequency & Percentage \\
\hline Very disatisfied & 3 & $0.96 \%$ \\
Disatisfied & 39 & $12.42 \%$ \\
Satisfied & 187 & $59.55 \%$ \\
Very satisfied & 84 & $26.75 \%$ \\
Extremely satisfied & 1 & $0.32 \%$ \\
\hline
\end{tabular}


Tabel 4. Correlation coefficient of medical staff service quality dimensions with patient's level of satisfaction

\begin{tabular}{ccccc}
\hline $\mathrm{R}$ & $\mathrm{R}$ Square & Adjusted $\mathrm{R}$ Square & Std. Error of the Estimate & Durbin-Watson \\
\hline $0.969^{\mathrm{a}}$ & 0.939 & 0.938 & 0.14414 & 1.820 \\
\hline
\end{tabular}

\subsection{Linear regression analysis of SERVQUAL model}

Based on Table 5 the significant value is 0.000 which shows that the linear regression model developed meets the linearity criteria. Additionally, a regression equation model can be obtained: $\mathrm{Y}=0.026+0.226 \mathrm{X} 1+0.332 \mathrm{X} 2+0.1 \mathrm{X} 3+0.075 \mathrm{X} 4+0.235 \mathrm{X} 5$ as shown in Table 6.

Tabel 5. Significance value of medical staff service quality dimensions with patient's level of satisfaction

\begin{tabular}{cccccc}
\hline Model & Sum of Squares & df & Mean Square & F & Sig. \\
\hline Regression & 98.016 & 5 & 19.603 & 943.482 & $0.000^{\mathrm{b}}$ \\
Residual & 6.400 & 308 & 0.021 & & \\
Total & 104.416 & 313 & & & \\
\hline
\end{tabular}

Tabel 6. Regression equation model

\begin{tabular}{|c|c|c|c|c|c|c|c|}
\hline \multirow{2}{*}{ Model } & \multicolumn{2}{|c|}{$\begin{array}{l}\text { Unstandardized } \\
\text { Coefficients }\end{array}$} & \multirow{2}{*}{$\begin{array}{c}\text { Standardized } \\
\text { Coefficients } \\
\text { Beta }\end{array}$} & \multirow{2}{*}{$\mathrm{t}$} & \multirow{2}{*}{ Sig. } & \multicolumn{2}{|c|}{$\begin{array}{l}95,0 \% \text { Confidence } \\
\text { Interval for B }\end{array}$} \\
\hline & B & $\begin{array}{l}\text { Std. } \\
\text { Error }\end{array}$ & & & & $\begin{array}{l}\text { Lower } \\
\text { Bound }\end{array}$ & $\begin{array}{l}\text { Upper } \\
\text { Bound }\end{array}$ \\
\hline (Constant) & .026 & .064 & & .409 & .683 & -.099 & .152 \\
\hline Reliability & .226 & .011 & .307 & 19.758 & .000 & .204 & .249 \\
\hline Assurance & .332 & .016 & .423 & 20.190 & .000 & .300 & .365 \\
\hline Tangible & .100 & .015 & .109 & 6.804 & .000 & .071 & .129 \\
\hline Empathy & .075 & .014 & .098 & 5.246 & .000 & .047 & .102 \\
\hline Responsiveness & .235 & .013 & .348 & 18.440 & .000 & .210 & .260 \\
\hline
\end{tabular}

The results of the study showed that overall RATER service quality dimension were relatively good (>3 on a scale of 5). The highest service quality dimension was on tangible dimension of 4.16. Assurance, tangible, empathy and responsiveness dimensions were marked very satisfied of 3.82, 4.16, 3.85 and 3.54. It generates the best feeling of patients during their hospitalization in the hospital. Tangibles were physical aspects that health service provider had including communication and adequate equipment. Hospitals are associated with nosocomial infection, so the management should concentrate on improving the physical appearance such as cleanliness in all hospital areas and providing infection control by medical staff. Previous study explained that customers made better decisions based upon cleanliness of the environment. This result could be used for measuring customer perceptions of cleanliness in a health service institution. Assurance dimension is the ability and knowledge of medical staff to provide services. Meanwhile empathy is the ability of medical staff to respect and accept while treating and caring the patients. Responsiveness represents willingness to provide prompt service and facilitate to solve patients' problems [14-16].

In the dimension of reliability, it was considered to be of sufficient of 3.41. Reliability was the provision of health services that should be given promptly, accurately, reliably and satisfactorily. Other study showed several aspects that can create a gap between patients' expectations and assumptions, such as taking care of patient's room, helping patients to solve the problems, motivation to provide better services and physical facilities [17]. Medical staff should give adequate information to the patients regarding their health complaints and treatment that will be provided by the hospital. To improve reliability dimension, there should be regular evaluation of medical staff and patients' satisfaction with medical staff performance, and increase in the number of medical staff during night rotations [18].

It was also found that $86.62 \%$ of respondents felt quite satisfied and were more than satisfied with medical staff services. Based on regression analysis results, five dimensions of health services quality affect patients' level of satisfaction and obtained the equation of $\mathrm{Y}=0.026+0.226 \mathrm{X} 1+0.332 \mathrm{X} 2+0.1 \mathrm{X} 3+0.075 \mathrm{X} 4+0.235 \mathrm{X} 5$, this explained that patients' satisfaction was affected by all dimensions of health service quality (RATER) simultaneously. However, different values will be obtained if all dimensions were measured separately, range from $10 \%$ to $33.2 \%$. This regression model showed that five service quality dimensions of Tangibles, Assurance, Responsiveness, Reliability and Empathy had significant influence and improved overall values of the service quality. 
Quality of hospital service is determined by patients' satisfaction, loyalty and hospital's productivity and profitability. In addition, patients' satisfaction also described about likes and dislikes of hospital service. Previous study argued that the primary focus to measure service quality of health care by analyzing service performance. Yet, current studies suggested that researchers should also explore the gap between patients' expectations and assumptions. Untachai et al. showed that hospital service quality was evaluated based on five basic dimensions of RATER and overall service quality in the hospital [19-21].

Hospital service quality could be evaluated by several methods. However, SERVQUAL method which was developed by Parasuraman was known as main tool to measure patients' perceptions and expectations. SERVQUAL questionnaire used 22-items within five dimensions: Tangibles, Assurance, Responsiveness, Reliability and Empathy. A study of Kayral investigated that dimensions of service quality had a significant difference between organization types of public hospitals and private and university hospitals $(\mathrm{p}<0.05)$. It was suggested that hospital should also prepare a policy strategy with regards to hospital management to improve the quality of its service [22-24].

Hospital competition creates positive effect on better provision of health services. High-quality services could be improved by meeting patients' needs and expectations. One of the key factors to improve quality of care is by having high quality medical staff. Hospital management should also improve the ability and performance of medical staff through continuing education and providing timeless rewards for outstanding medical staff. Patients' perceptions of health services could affect the image of the hospital as well as patients' loyalty [25-27].

\section{CONCLUSION}

Five dimensions of health services quality affect patients' level of satisfaction. To be concluded, patients' satisfaction was affected by all dimensions of health service quality (RATER) simultaneously. The quality of medical staff services influenced by its five components: reliability, assurance, tangible, empathy and responsiveness.

\section{ACKNOWLEDGEMENTS}

We would like to thank you to all respondents for their contribution in this study. Our special thanks to Doctoral Program of Public Health, Faculty of Public Health, Universitas Airlangga and Faculty of Medicine, University of Muhammadiyah Malang to conduct this research.

\section{REFERENCES}

[1] T. Fatima, S. A. Malik, A. Shabbir, "Hospital healthcare service quality, patient satisfaction and loyalty: An investigation in context of private healthcare systems," International Journal of Quality \& Reliability Management, Vol. 35, Issue: 6, pp.1195-1214, 2018.

[2] V. Budiwan and Efendi, "The Understanding of Indonesian Patients of Hospital Service Quality in Singapore," Procedia - Social and Behavioral Sciences, Vol. 224, pp. 176 - 183, 2016.

[3] C-S. Chang, S-Y. Chen and Y-T. Lan, "Service quality, trust, and patient satisfaction in interpersonal-based medical service encounters," BMC Health Services Research, Vol. 13:22, pp. 1-11, 2013.

[4] D.C. Ferreira and R.C. Marques, "Do quality and access to hospital services impact on their technical efficiency?," Omega, Vol. 15-22, pp. 1-19, 2018.

[5] P. W. Handayani, A. N. Hidayanto, P. I. Sandhyaduhita, Kasiyah and D. Ayuningtyas, "Strategic hospital services quality analysis in Indonesia," Expert Systems with Applications, Vol. 42, pp. 3067-3078, 2015.

[6] R. Kalaja, R. Myshketa, F. Scalera, "Service quality assessment in health care sector: the case of Durres public hospital," Procedia - Social and Behavioral Sciences, Vol. 235, pp. 557 - 565, 2016.

[7] M. Mankar, D. Velankar, S. Joshi and A. Nalgundwar, "A Study of Patient Satisfaction Towards Out Patient Department Services (OPD) of A Hospital and Research Centre Using Exit Interview," Indian J. Prev. Soc. Med., Vol. 44, No.1-2, 2013.

[8] I. Janicijevic, K. Seke, A. Djokovic and J. Filipovic, "Healthcare workers satisfaction and patient satisfaction where is the linkage?," Hippokratia, Vol. 17, No. 2, pp. 157-162, 2013.

[9] M. Shafii, S. Rafiei, F. Abooee, M. A. Bahrami, M. Nouhi, F. Lotfi and K. Khanjankhani, "Assessment of Service Quality in Teaching Hospitals of Yazd University of Medical Sciences: Using Multi-criteria Decision Making Techniques," Osong Public Health Res Perspect, Vol. 7(4), pp. 239-247, 2016.

[10] A. Parasuraman, V.A. Zeithaml and L.L. Berry, "A conceptual model of service quality and its implications for future research,” Journal of Marketing Research, Vol. 49, pp. 41-50, 1985.

[11] O. T. Alex and K. Paul, "Applicability of SERVQUAL/RATER Model in Assessment of Service Quality Among Local Authorities in Kenya A Survey of Residents of Nakuru Town," International Journal of Economics, Commerce and Management, Vol. II, Issue 12, pp. 1-16, 2014. 
[12] N. K. Alimana and W. N. Mohamad, “Linking Service Quality, Patients' Satisfaction and Behavioral Intentions: An investigation on Private Healthcare in Malaysia," Procedia-Social and Behavioral Sciences, Vol. 224, pp. 141-148, 2016.

[13] M. Badlani and D. K. Singhal, "Analysis of Service Quality Gap Using SERVQUAL Model: An Indian Petro Retailing Scenario," International Journal of Business and Management Invention, Volume 6, Issue 7, pp. 68-71, 2017.

[14] R. Rosha and N. Kaur, "Relationship between RATER Service Quality Dimensions and Customer SatisfactionStudy on Travel agents in Punjab," Journal of Arts, Science \& Commerce, Vol. IX, Issue 1, pp 160-164, 2018.

[15] A. Solayappan, J. Jayakrishnan and S. Velmani, "Quality Measurement for Hospital Services," IPEDR, Vol.12, 2011.

[16] N. Barber and J. M. Scarcelli, "Enhancing the assessment of tangible service quality through the creation of a cleanliness measurement scale," Managing Service Quality, Vol. 20, No. 1, pp. 70-88, 2010.

[17] A. Nadi, J. Shojaee, G. Abedi, H. Siamian, E. Abedini and F. Rostami, "Patients' Expectations and Perceptions of Service Quality in the Selected Hospitals," Med Arch, Vol. 70(2), pp. 135-139, 2016.

[18] M. Razmjoee, M. Yadollahi and N. Shamsedini, "Patients' Satisfaction with Service Quality of a Public Hospital: An Evaluation Study (SERVQUAL Model)," J Health Sci Surveillance Sys, Vol 5, No 2, pp. 66-71, 2017.

[19] S. Untachai, "Modeling Service Quality in Hospital as a Second Order Factor, Thailand," Procedia-Social and Behavioral Sciences, 88, 118 - 133, 2013.

[20] O. Kitapci, C. Akdogan, I. T. Dortyol, "The Impact of Service Quality Dimensions on Patient Satisfaction, Repurchase Intentions and Word-of-Mouth Communication in the Public Healthcare Industry," Procedia-Social and Behavioral Sciences, 148, 161-169, 2014.

[21] I. A. C. Mendes, M. A. Trevizan, S. D. Godoy, P. C. Nogueira, C. A. A. Ventura, C. E. B. Furlan, "Expectations and perceptions of clients concerning the quality of care provided at a Brazilian hospital facility," Applied Nursing Research, 39, 211-216, 2018.

[22] I. Kayral, "Perceived Service Quality in Healthcare Organizations and a Research in Ankara by Hospital Type," Journal of Ankara Studies, 2(1), 22-34, 2014.

[23] S. Behdioğlu, E. Acar \& H. A. Burhan, "Evaluating service quality by fuzzy SERVQUAL: a case study in a physiotherapy and rehabilitation hospital," Total Quality Management \& Business Excellence, 1-19, 2017.

[24] Riono and Ahmadi, “Analysis of Healthcare Services Quality Using Servqual - Fuzzy Method," Int J Econ Manag Sci, 6:6, 2017.

[25] A. Zarei, M. Arab, A. R. Froushani, A. Rashidian and S. M. G. Tabatabaei, "Service quality of private hospitals: The Iranian Patients' perspective," BMC Health Services Research, Vol. 12:31, pp 1-7, 2012.

[26] M. Li, D. B. Lowrie, C-Y. Huang, X-C. Lu, Y-C. Zhu, X-H. Wu, M. Shayiti, Q-Z Tan, H-L. Yang, S-Y Chen, P. Zhao, S-H. He, X-R. Wang and H-Z. Lu, "Evaluating patients' perception of service quality at hospitals in nine Chinese cities by use of the ServQual scale," Asian Pac J Trop Biomed, Vol. 5(6), pp.497-504, 2015.

[27] M. Shafiq, M. A, Naeem, Z. Munawar and I. Fatima, "Service Quality Assessment of Hospitals in Asian Context: An Empirical Evidence," The Journal of Health Care Organization, Provision, and Financing, Vol. 54, pp. 1-12, 2017.

\section{BIOGRAPHIES OF AUTHORS}

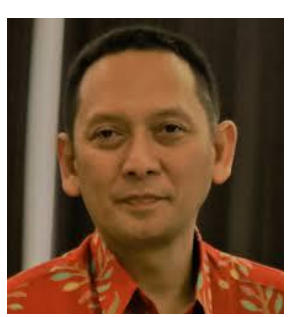

Febri Endra Budi Setyawan is a lecturer at Faculty of Medicine, University of Muhammadiyah Malang. His specialty is in epidemiology, primary care, family medicine and industrial medicine. He received his bachelor of medical education in Faculty of Medicine, University of Brawijaya. His master of public health was achieved from Universitas Airlangga.

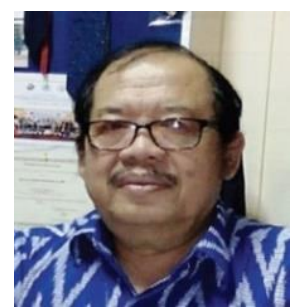

Stefanus Supriyanto is a lecturer at the Faculty of Public Health, Universitas Airlangga. His specialty is management of health policies that include hospitals, health departments, community health centers and clinics. He received his bachelor of medical education in Faculty of Medicine Universitas Airlangga. His master of public health was achieved from Universitas Airlangga. His doctoral program was obtained through a sandwich program from the Directorate General of Higher Education. He was inaugurated as professor on the accuracy of health reform by doing reorientation, restructuring, and development of health financing systems, partnerships, and empowerment. 


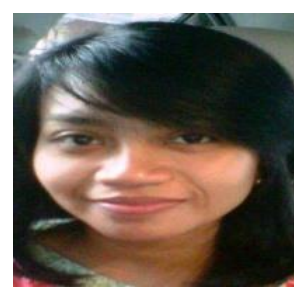

Feny Tunjungsari is a lecturer at Faculty of Medicine, University of Muhammadiyah Malang. Her specialty is in public health, family medicine and industrial medicine. She received her bachelor of medical education in Faculty of Medicine, University of Muhammadiyah Malang. Her master of public health was achieved from Sebelas Maret University.

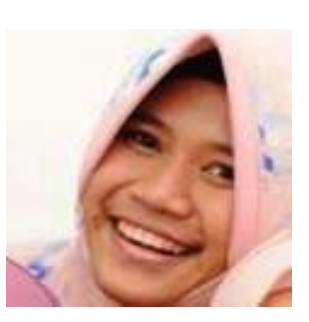

Wa Ode Nurlaily Hanifaty is a medical education student in Faculty of Medicine, University of Muhammadiyah Malang. Currently, she is doing clinical attachment in her medical study to improve her clinical performance in hospitals and community.

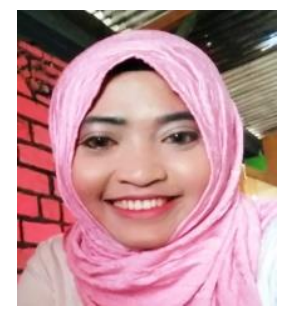

Retno Lestari is a lecturer at Study Program of Nursing Science, Faculty of Medicine, University of Brawijaya. Her specialty is in mental health nursing. She received her bachelor of nursing in Nursing Faculty, University of Indonesia. Her master of nursing was achieved from Monash University, Australia. 